\begin{tabular}{|c|c|c|}
\hline & Our Nature & $\begin{array}{l}\text { ISSN: 1991-2951 (Print) } \\
\text { ISSN: 2091-2781 (Online) }\end{array}$ \\
\hline $\begin{array}{l}\text { Noture Conservation \& } \\
\text { Healith Care Councill } \\
\text { Birathogat Nopd }\end{array}$ & Journal homepage: http://nepjol.info/index.php/ON & (c) \\
\hline
\end{tabular}

\title{
The morphohistology and fine anatomy of the olfactory organ in pabda catfish, Ompok bimaculatus (Bloch, 1794)
}

\author{
Saroj Kumar Ghosh \\ Department of Zoology, Bejoy Narayan Mahavidyalaya, Itachuna, Hooghly-712 147, West Bengal, \\ India \\ E-mail: saroj.fisherylab@gmail.com
}

\begin{abstract}
The organization of the olfactory system in Ompok bimaculatus (Siluriformes: Siluridae) were investigated by histological and ultrastructural analysis. The nasal chamber was totally engrossed by a boat shaped elongated olfactory rosette with numerous lamella. Histomicroscopically, each lamella was comprised of central core bounded on both sides by the cellular elements of olfactory epithelium. The central core was composed of thick connective tissue, nerve fibres and blood capillaries. The cellular components of the olfactory epithelium were identified based on their staining vigour, architecture, structural characteristics and surface features. The sensory epithelium contained morphologically recognizable ciliated, microvillous and rod receptor neurons. Labyrinth cells, scattered lymphatic cells, secretory mucous cells, stratified epithelial cells bearing microfolds and condensed ciliated supporting cells were observed in the indifferent epithelia. The basal cells were submerged in the deeper zone of mucosa above the basal lamina. Different sensory and nonsensory cells of the olfactory lining were associated with chemical stimulation of the fish studied. This species acquires a well developed olfactory sense for exploring the aquatic environment and able to determine the chemical changes in the surroundings.
\end{abstract}

Key words: Butter catfish, Cellular constituent, Chemoreception, Microarchitecture, Olfactory mucosa

\footnotetext{
DOI: https://doi.org/10.3126/on.v18i1.34237

Manuscript details: Received: $18.10 .2020 /$ Accepted: 19.12.2020

Citation: Ghosh, S.K. 2020. The morphohistology and fine anatomy of the olfactory organ in pabda catfish, Ompok bimaculatus (Bloch, 1794) Our Nature 18 (1): 10-15. DOI: https://doi.org/10.3126/on.v18i1.34237

Copyright: Ghosh. Creative Commons Attribution - Non Commercial 4.0 International License.
}

\section{Introduction}

Olfactory sense is mediated to be the first range of chemosensory systems for behavioural adjustments. Olfactory system of fish has high sensitivity and selectivity permitting olfaction to function as distance chemical sense (Devitsina and Chervova, 1994). Smell is the considerable mediator of chemical communication and necessitated for various fish behaviour. Fish have well organized olfactory organs which play momentous role in food searching, predator detection, kin finding, nest locating, breeding sites recognition, reproductive and other behaviours (Farbman, 1994). The olfactory sensitivity of teleosts has some peculiarities as olfaction occurs in an aquatic environment. Diversity exists with regard to the morphology of olfactory organs and cellular organizations in the mucosa. In teleostean fishes the structural peculiarity and function of olfactory apparatus is related to their ecological specificity and mode of life. Olfactory mucosa consists of a mosaic of sensory neurons, classified as ciliar, microvillar, rod and crypt receptor cells reported by many workers in teleosts (Diaz et al., 2002; Hamdani et al., 2008; Kuciel et al., 2011; Mokhtar and Abd-Elhafeez, 2014; Ghosh, 2020). Appearance 


\section{Our Nature | December 2020 | 18 (1): 10-15}

of different kinds of neurons on olfactory lining is bounded to distinct chemical stimuli and responsible for unequivocal reactions.

Ompok bimaculatus is a carnivorous freshwater catfish; feeds on aquatic insects, shri-mps, zooplanktons, mollusks, oligochates and other small fishes (Arthi et al., 2011, Gupta, 2015). The knowledge of olfactory structure in Indian butter catfish is almost unknown. The aim of the present investigation is to delineate the cellular details and minute anatomy of the olfactory organ in silurid catfish, Ompok bimaculatus (Bloch, 1794) by light as well as scanning electron microscopy.

\section{Materials and methods Collection of samples}

The adult specimens of $O$. bimaculatus (body length ranging 21.2-25.4 cm) were collected alive from Kalyani Field Station of Regional Research Centre of Central Institute of Freshwater Aquaculture, Santalapara, Nadia, West Bengal. Samples were anaesthetized with ethyl 3-aminobenzoate methanesulfonate (MS-222; Merck) solution $(100 \mathrm{mg} / \mathrm{L})$ and sacrificed at the field obeying the guidelines of the institutional animal ethics committee. The olfactory rosettes were carefully dissected out soon and progressed for the histomicroscopical and scanning electron microscopical considerations.

\section{Histological procedure}

The olfactory organs were kept in aqueous Bouin's fluid for 18-24 hour. After washed properly in $70 \%$ ethanol, the samples were dehydrated through graded series of ethanol and cleared with methyl benzoate. The tissues were embedded in paraffin wax of $56-58^{\circ} \mathrm{C}$ (Oxford Lab Fine Chem LLP) for 1 hour and sectioned at $4 \mu \mathrm{m}$ thick using Weswox MT-1090A rotary microtome. After routine method, the dewaxed sections were stained with Azan Trichome (AT) (Heidenhain, 1915) and Delafield's Haematoxylin-Eosin (HE) (Fischer et al., 2008). Stained sections were mounted with dibutylphthalate polystyrene xylene and observed under Carl ZEISS Primo Star light microscope set up with Tucsen 5.0 MP microscope camera.

\section{Scanning electron microscopical procedure}

After exposed, the olfactory rosettes within cavity were dipped in a solution containing $2.5 \%$ glutaraldehyde buffered with $0.1 \mathrm{M}$ phosphate buffer ( $\mathrm{pH}$ 7.4) for 10-15 minutes. Next the entire olfactory rosettes were dissected out and washed well with 1\% Tween 40 (Polyoxyethylenesorbitan monopalmitate) solution to clear away the mucus and debris from the surface. The samples were rinsed in the same buffer, fixed in $2.5 \%$ glutaraldehyde for 24 hours at $4^{\circ} \mathrm{C}$ and postfixed in $1 \% \quad 0.1 \mathrm{M}$ phosphate buffered osmium tetroxide ( $\mathrm{pH}$ 7.4) for further 2 hours at room temperature. Then they were dehydrated with acetone, immersed in isoamyl acetate, critical point dried with liquid $\mathrm{CO}_{2}$ (Cohen et al., 1968) and mounted with glue on aluminium stubs. After sputter coated (BT-150 Coater, Hind High Vacuum Co. Pvt. Ltd.) with platinum, the samples were visualized with ZEISS EVO 18 scanning electron microscope.

\section{Results}

Ompok bimaculatus (Fig. 1A) possessed a pair of nasal chambers bearing olfactory rosettes together with associated structures embedded in the fossa molded at the ethmoid region of the skull (Fig. 1B). The elongated boat shaped olfactory rosettes were engrossed the total space of nasal chambers and bounded with surrounding bony portions by connective tissue fibres (Fig. 1C). A narrow raphe was observed on the dorsal concave surface of the rosette which consisted about 20-24 olfactory lamellae of various sizes. The flattened lamellae were arranged parallel series to each another in a vertical direction. A conspicuous interlamellar space existed which aided the sufficient water flow over the surface of lamella. The lamellae were broad in the midway of rosette and decreased in width towards both sides. These abide conjoined to the bottom of nasal chamber by their ventral edges and a substantial expanse to the side walls of cavity. They were affixed laterally to the medial longitudinal raphe by proximal endings. The lamellae were dorsally free and provided with tongue like linguiform processes in a precise order (Fig. 1D). Each lamella was differentiated into sensory and nonsensory zones. The sensory islets were confined on linguiform processes whereas the resting greater part of lamellae contained nonsensory cells. 
Our Nature | December 2020 | 18 (1): 10-15

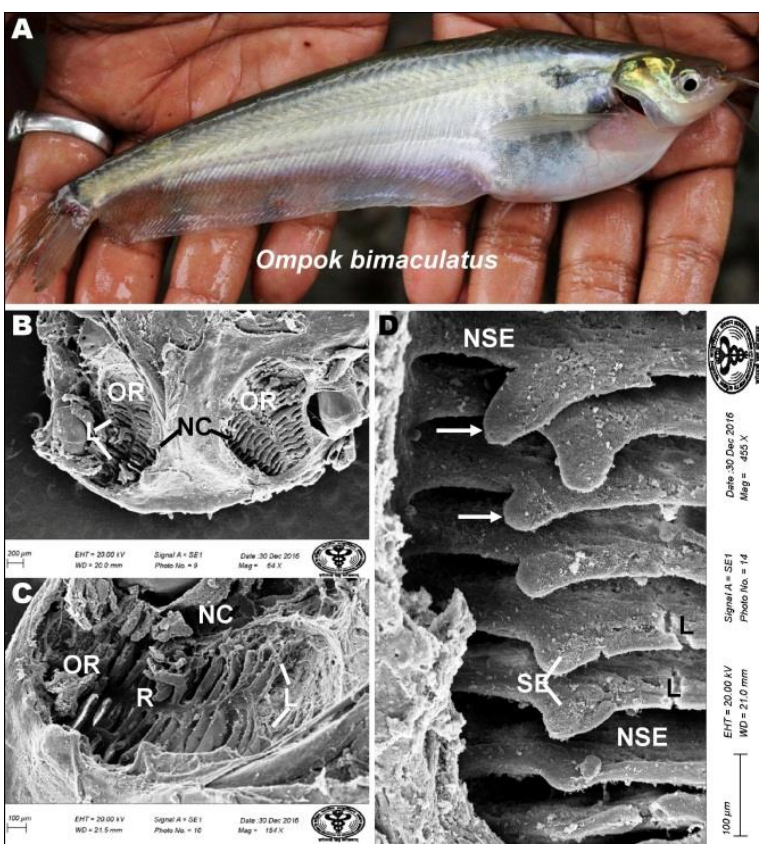

Fig. 1. Structure of the olfactory organ in $O$. bimaculatus. (A) Lateral view of Ompok bimaculatus. (B) Dorsal view of skull showed olfactory rosettes (OR) having a series of lamellae (L) within nasal chambers (NC). (C) Olfactory rosette (OR) within nasal chamber (NC) consisted of parallel organized lamellae from central raphe (R). (D) Lamellae (L) exhibited sensory (SE) and nonsensory (NSE) region. Arrows marked linguiform processes on lamellae.

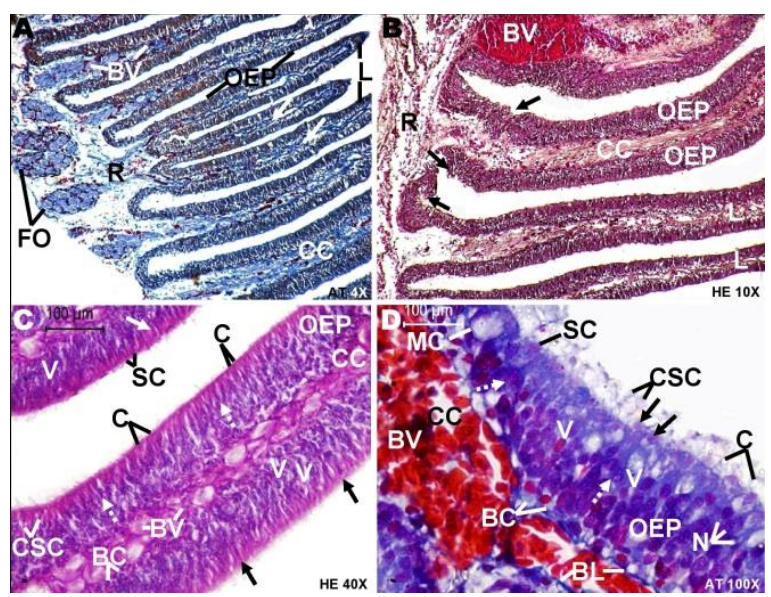

Fig. 2. Photomicrographs of the transverse section of olfactory rosette of $O$. bimaculatus stained with Azan Trichome (AT) and Delafield's Haematoxylin-Eosin (HE). (A) Transverse section of an olfactory rosette showing olfactory lamellae (L) radiated from raphe (R). L composed of olfactory epithelium (OEP) and central core (CC) which contained nerve fibres (arrows) and blood vessels (BV). FO marked fila olfactoria. (B) Lamellae (L) attached with raphe (R) exhibited OEP and CC with BV. Arrows indicated the folded regions of lamellae. (C) OEP typified with primary receptor cells (C), rod cells (broken arrows), labyrinth cells (solid arrows), lymphatic cells (arrow heads), ciliated supporting cells (CSC), nonciliated supporting cells (SC) and basal cells (BC). Note the presence BV in CC (D) Magnified OEP exhibited primary receptor cells $(\mathrm{C})$ with prominent nuclei $(\mathrm{N})$, microvillous receptor cells (solid arrows), rod receptor cell (broken arrow), mucous cell (MC), lymphatic cells (arrow heads), CSC, SC and BC. CC containing a large number of $\mathrm{BV}$ separated from $\mathrm{OEP}$ by basal lamina (BL).

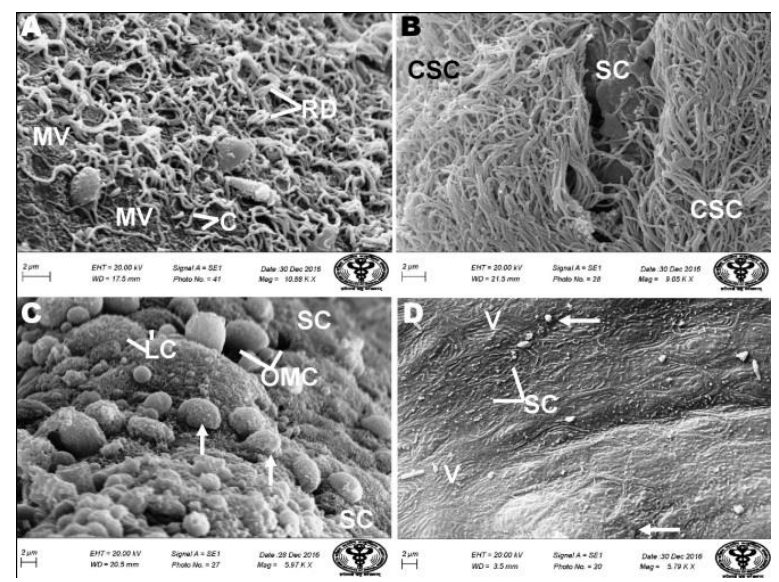

Fig. 3. Scanning electron photomicrographs exhibiting the surface of olfactory epithelium in $O$. bimaculatus. (A) Sensory epithelium equipped with ciliated receptor cells (C), microvillous receptor cells (MV) and rod receptor cells (RD). (B) Nonsensory epithelium showing tuft of ciliated nonsensory cells (CSC) and stratified epithelial cells (SC). (C) Surface of nonsensory epithelium manifesting labyrinth cells (LC), opening of mucous cells (OMC) and SC. Arrows marked mucin masses over SC. (D) Raphe represented by concisely arranged SC with microridged (arrow heads). Note the opening of mucous cells (solid arrows) amongst SC.

Histologically the olfactory lamellae attached laterally on raphe, were composed of submucosa or central core which bounded on both sides by cellular constituents of epithelium or mucosa (Fig. 2A). The submucosa was composed of roughly distributed connective tissue fibres, blood vessels and bunch of nerve fibres. The distinguishable basal lamina was marked in between mucosa and submucosa (Fig. 2D). The well organized mucosa showed disparity in thickness in all olfactory lamella and retained some folds to enhance the surface lining (Figs. 2A and B). The olfactory mucosa consisted of sensory receptor cells and diversified nonsensory cells. The receptor cells having apical sensory hairs and basally located nuclei were compactly organized in the surface zone of mucosa. Primary receptor cells contained ovoid dark nuclei and fibrillar dendrites to the epithelial border (Fig. 2C). The terminal end of dendrite acquired a deeply stained protrusion, 


\section{Our Nature | December 2020 | 18 (1): 10-15}

the receptor vesicle which embossed with pointed cilia (Fig. 2D). Microvillous receptor cells were placed closing to the mucosal zone, packed with fairly stained rounded nuclei and granulated cytoplasm. Rod receptor cells possessed intensely stained spindle shaped nuclei and dendritic elongations facing to the interlamellar space. The nonsensory epithelium contained labyrinth cells, lymphatic cells, mucous cells and supporting cells. Labyrinth cells were disseminated irregularly in the mucosal boundary. They were moderately larger and apparently globose in shape with medially placed basophilic nuclei (Fig. 2C). Lymphatic cells were distributed throughout the mucosa, comprehended distinct nuclei and coarse grained cytoplasm (Figs. 2C and D). Mucous cells were empty in nature due to release their contents on the epithelial surface (Fig. 2D). Supporting cells were appeared in between the receptor cells and distinguished into ciliated as well as nonciliated types (Figs. 2C and D). The ciliated supporting cells were elevated and intercalated in the proximal part of the olfactory lamella. Nuclei were stained with haematoxylin, located in the inner limb. The cytoplasm exhibited granular features and distal portion of the cells were sculpted with cilia. The nonciliated supporting cells were afforded with profoundly stained nuclei which situated at the outer limb and faintly discernible chromatin materials. The basal cells were occurred nearly basal lamina, possessed bulging prominent nuclei (Figs. 2C and D).

Scanning electron microscopy revealed the surface morphology and topological properties of the olfactory cells on the mucosa. Ciliated receptor cells were appeared as narrow hillock like extrimities originated from periphery. The microvillous receptor cells were covered with crowded microvilli like protrusions which manifested harsh texture over the epithelial surface. Rod shaped receptor cells were occasionally observed, distended as compound tips facing the mucosal lining. The terminal ends of rod cells gradually diminished towards the tip (Fig. 3A). Spherical labyrinth cells with folded sheath were notable as pellet like appearance over the olfactory lining (Fig. 3C). The nonsensory epithelia mainly composed of stratified epithelial cells containing microfolds and compressed ciliated supporting cells intercalated with mucous cells. Condensed nonsensory cilia furnished the spongy facet over the lamella (Fig. 3B). Numerous mucin balls were observed over free epithelial surface (Fig. $3 \mathrm{C})$. The central axis or raphe was made up of integrated stratified epithelial cells bearing aligned microridges alter with corrugation (Fig. $3 \mathrm{D})$. Opening of mucous cells were viewed in between stratified epithelial cells.

\section{Discussion}

Chemical communication is associated with the development of chemosensory organs and chemical signals are effused in aquatic environments by different teleosts (Hara, 2000). Chemical stimuli are detected by the apical dendritic parts of sensory cells lining olfactory mucosa and admissible behaviours revealed by organisms. $O$. bimaculatus have elongated olfactory rosettes with a series of lamellae, lodged at the ethmoid region of the skull. Such type of olfactory organ falls into Teichmann's (1954) third category i.e., nose fishes, in which olfaction better than sight. Such kind of olfactory organ belongs to Pol Gerard's (1954) third category i.e., macrosmic, in which fish possesses well developed sense of smell for searching the food. Base on lamellar distribution, it is classified Yamamoto (1982) Type-H i.e., double siding comb like appearance along the midline raphe. The folding of olfactory lamella enhances the olfactory surface area as well as efficiency of olfactory system (Zeiske et al., 1976). The lamellae bear specialized linguiform processes which forward the movement of water over the olfactory rosette. This organization possibly in that the sensory islets containing chemosensory cells face the flow of incoming water current. Distribution of sensory and nonsensory cells on the lamellae furnishes immense diversity among teleostean fishes concomitant with their varying habits and behaviour (Yamamoto, 1982).

There are three morphological types of receptor cells: those with ciliated edges or those with microvillar tips or rod like projections. Hansen and Zeiske (1998) advocated that receptor cells containing odorant receptors expose the stimuli and turn over the message to the olfactory bulb. Zippel et al. (1997) reported that ciliated neurons perform counter to amino acids while the microvillous cells mediate comeback to pheromones. The olfactory knob with sensory hairs and microvilli of receptor cells implies various useful activities and skill for recognition of chemical cues (Mokhtar and Abd-Elhafeez, 2014). Datta and Bandyopadhyay (1997) reported that rod cell is not a usual 


\section{Our Nature | December 2020 | 18 (1): 10-15}

subtype, the forming of rod probably due to fusion of cilia of ciliated region. Hernadi (1993) reported that the presence of the rod cell due to habitat of a new physiological climate. Existence of rod receptor cells reveals the marking of aged ciliated receptor cells (Yamamoto, 1982).

The labyrinth cells are unique for olfactory epithelium, probably help to sustain an optimal ion regulation involving electrolyte transport, have considerable ecological significance (Bertmer, 1972). Presence of lymphatic cells all through the epithelia functions as component of cell immunity (Lieschke and Trede, 2009). Similar findings were also reported in olfactory organ of Micropterus salmoides (Kim et al., 2019). Mucous cells secrets mucin which protects the mucosa and helps in binding the microscopic particles to keep the sensory neurons accessible for new odorants. The mucus film over the epithelial lining may also nurse and perform as an ion trap, which prevent the contact of salts and heavy metal to beneath cells (Banerjee, 1993). Stratified epithelial cells help in mechanical dissociation and to secrete substances over the olfactory lamella (Hara, 1994). The cilia of supporting cells drive incoming water with odorant molecules over the tips of receptor neurons (Hara, 2000). The beating of cilia also propels mucin over the lamella. The basal cells are the precursors of regenerating receptor cells and other supporting cells (Zeiske et al., 1992). They are localized deep in the epithelia, able to sustain the mucosa during normal cell death or necrobiosis.

\section{Conclusion}

$O$. bimaculatus acquires a well developed olfactory sense for exploring the aquatic environment in which they inhabit. Occurrence of different kinds of sensory neurons is able to judge the chemical changes in the surroundings. For better understanding the olfactory sensitivity and chemical stimulation of the organism, more experimental works are suggested in future.

\section{Acknowledgements}

The author is indebted to the authority of Sophisticated Analytical Instrumentation Facility, All India Institute of Medical Sciences, New Delhi-110029 for technical assistance in scanning electron microscopy and thankful to Kalyani Field Station, Regional Research Centre of Central Institute of Freshwater Aquaculture, Santalpara, Nadia-741235 for given the fish.

\section{References}

Arthi, T., S. Nagarajan and A.A. Sivakumar 2011. Food and feeding habits of two freshwater fishes, Ompok bimaculatus and $O$. malabaricus of river Amaravathy, Tamil Nadu. The Bioscan, 6(3): 417-420.

Banerjee, T.K. 1993. Response of fish skin to certain ambient toxicants. In Advances in fish research (Eds. B.R. Singh). Narendra Publishing House, Delhi. pp. 185-192.

Bertmar, G. 1972. Labyrinth cells, a new cell type in vertebrate olfactory organs. Zeitschrift für Zellforschung und Mikroskopische Anatomie 132: 245-256. DOI: https://doi.org/10.1007/BF00307014.

Cohen, A., D. Marlow and G. Garner 1968. A rapid critical point method using fluorocarbon ("freons") as intermediate and transitional fluids. Journal of Microscopy, 7: 331-342.

Datta, N.C. and S. Bandopadhyay 1997. Ultrastructure of cell types of the olfactory epithelium in a catfish, Heteropneustes fossilis (Bloch). Journal of Bioscience, 22: 233-245. DOI: https://doi.org/10.1007/ BF02704736.

Devitsina, G.V. and L.S. Chervova 1994. Morphological and physiological aspects of fish chemorecption. In Advances in fish biology (Eds. H.R. Singh). Hindustan Publishing Corporation, Delhi. pp. 185-191.

Diaz, J.P., M. Prié-Granié, C. Blasco, T. Noëll and R. Connes 2002. Ultrastructural study of the olfactory organ in adult and developing European sea bass, Dicentrarchus labrax. Canadian Journal of Zoology, 80(9): 16101622.

Farbman, A.I. 1994. The cellular basis of olfaction. Endeavour, 18(1): 2-8. DOI: https://doi.org/10.1016/0160-9327(94)901 147.

Fischer, A.H., K.A. Jacobson, J. Rose and R. Zeller 2008. Hematoxylin and eosin staining of tissue and cell sections. Cold Spring Harbor Protocol, 5: 1-3. DOI: 10.1101/pdb.prot4986.

Ghosh, S.K. 2020. The olfactory organ in the Gangetic catfish, Ailia coila (Hamilton, 1822): structural and functional aspects. Journal of Fisheries, 8(2): 843-849.

Gupta, S. 2015. An overview on feeding habit, reproductive biology and induced breeding of Ompok bimaculatus (Bloch, 1794). European Journal of Biological Sciences. 7(4): 147-153. DOI: 10.5829/idosi.ejbs. 2015.7.04.95163.

Hamdani, E.H., S. Lastein, F. Gregersen and K.B. Døving 2008. Seasonal variations in olfactory sensory neurons-fish sensitivity to sex pheromones explained. Chemical Senses, 


\section{Our Nature | December 2020 | 18 (1): 10-15}

33(2): 119-123. DOI: https://doi. org/10.1093/ chemse/bjm072.

Hansen, A. and E. Zeiske 1998. The peripheral olfactory organ of the zebrafish, Danio rerio: an ultrastructural study. Chemical Senses, 23(1): 39-48. DOI: https://doi.org/ 10. 1093/ chemse/23.1.39.

Hara, T.J. 1994. The diversity of chemical stimulation in fish olfaction and gestation. Reviews in Fish Biology and Fisheries, 4: 1-35. DOI: 10.1007/BF00043259.

Hara, T.J. 2000. Chemoreception. In The laboratory fish (Eds. G.K. Ostrander). Academic press, London. pp. 471-479.

Heidenhain, M. 1915. Über die Mallorysche Bindegewebsfärbung mit Karmin und Azokarmin als Vorfarben. Zeitschrift für wissenschaftliche Mikroskopie und mikroskopische Technik, 32: 361-372. DOI: https://doi.org/10. 1007 /BF02084270.

Hernádi, L. 1993. Fine structural characteriza-tion of the olfactory epithelium and its response to divalent cations $\mathrm{Cd}^{2+}$ in the fish Alburnus alburnus (Teleostei, Cyprinidae): a scanning and transmission electron microscopic study. Neurobiology, 1(1): 11-31.

Kim, H.T., S.W. Yun and J.Y. Park 2019. Anatomy, ultrastructure and histology of the olfactory organ of the largemouth bass Micropterus salmoides, Centrarchidae. Applied Microscopy, 49: 1-6.

Kuciel, M., K. Żuwala and M. Jakubowski 2011. A new type of fish olfactory organ structure in Periophthalmus barbarous (Oxudercinae). Acta Zoologica, 92: 276-280. DOI: https:// doi.org/10.1111/j.1463-6395.2010.00 459.x.
Lieschke, G.J. and N.S. Trede 2009. Fish immunology. Current Biology, 19(16): 678-682.

Mokhtar, D.M. and H.H. Abd-Elhafeez 2014. Light-and electron-microscopic studies of the olfactory organ of red-tail shark, Epalzeorhynchos bicolor (teleostei: cyprinidae). Journal of Microscopy and Ultrastructure, 2(3): 182195. DOI: https://doi.org/10.1016/j.jmau.20 14.05.003.

Pol Gerard 1954. Organe olfactif. Traité de Zoologie, 12: 522-533.

Teichmann, H. 1954. Vergleichende Untersuchungen an der Nase der Fische. Zeitschrift für Morphologie und Ökologie der Tiere, 43: 171-212.

Yamamoto, M. 1982. Comparative morphology of the peripheral olfactory organ in teleosts. In Chemoreception in fishes (Eds. T.J. Hara). Amsterdam, Elsevier. pp. 35-59.

Zeiske, E., R. Mellinkat, H. Breucker and J. Kux 1976. Ultrastructural studies on the epithelia of the olfactory organ of Cyprinodonts (Teleostei, Cyprinodontoi-dae). Cell and Tissue Research, 172: 245-267. DOI: https:// doi.org /10.1007/BF00 226030.

Zeiske, E., B. Theisen and H. Breucker 1992. Structure, development and evolutionary aspects of the peripheral olfactory system. In Fish chemoreception (Eds. T.J. Hara). Chapmann and Hall, London. pp. 13-39.

Zippel, H.P., P.W. Sorensen and A. Hansen 1997. High correlation between microvillous olfactory receptor cell abundance and sensitivity to pheromones in olfactory nervesectioned goldfish. Journal of Comparative Physiology, 180: 39-52. DOI: https://doi.org/ 10. $1007 / \mathrm{s} 003590050025$. 